\title{
PENGARUH BAHASA TERHADAP PERBEDAAN PENDAPAT PARA IMAM MUJTAHID DALAM MENAFSIRKAN AYAT-AYAT HUKUM
}

\author{
Kadar M. Yusuf \\ Fakultas Tarbiyah dan Keguruan UIN Sulthan Syarif Kasim Riau \\ Jl. Subrantas Km. 15, 5 Panam, Pekanbaru \\ e-mail: lailatul_qdr@yahoo.com
}

\begin{abstract}
Abstrak: Pada tataran tertentu, para ulama berbeda dan tidak sepakat tentang beberapa persoalan hukum. Ketidaksepakatan itu dilatarbelakangi oleh berbagai hal, salah satu di antaranya adalah persoalan kebahasaan. Artikel ini membahas bagaimana para mujtahid berbeda dalam menafsirkan ayat-ayat hukum yang menurut penulis terdiri dari enam aspek, yaitu 1) pemaknaan h hurûf jâr dan hurûf 'athf, 2) penentuan makna ficil (kata kerja) dan ism (kata benda), 3) menentukan objek yang ditunjuki ism isyârah, 4) menentukan tempat pengembalian ism dhamîr, 5) menentukan kuantitas dan kualitas makna suatu lafal, dan 6) penentuan makna haqî̀qy atau majâzy suatu lafal. Penulis mengemukakan bahwa sebagai konsekuensi dari perbedaan kebahasaan ini, para imam mujtahid memiliki pemahaman dan penafsiran yang berbeda terhadap ayat-ayat hukum Islam, yang pada gilirannya melahirkan keragaman umat Islam dalam beribadah dan bermuamalah.
\end{abstract}

\begin{abstract}
The Linguistic Influence on the Divergence of Jurisprudents Opinion in Interpreting Qur'anic Legal Verses. At certain level, the jurisprudents disputed and disagreed on a number of legal issues. Such disagreement stems from various aspects, one of which is linguistic problem. This article studies how the jurisprudents are different in interpreting legal verses, which according to the author consists of six aspects, namely identifying hurûf jâr (preposition) and huurûf 'athf (conjuntion); determining the meaning of fill (verb) and ism (noun); deciding the object to which ism isyârah and pronoun refers to; deciding quantity and quality of the meaning of a word and sentence; and identifying ma'na haqîqy (definite or real meaning) of a word and sentence and its ma'na majâzy (metaphor). The author argues that as a consequence of these differences, Muslim scholars have different understanding of Islamic legal verses, which in turn lead to divergence of implementation of Islamic laws within the Muslim community both in the ritual and social dealings.
\end{abstract}

Kata Kunci: hukum Islam, perbedaan pendapat, bahasa, penafsiran 


\section{Pendahuluan}

Sudah menjadi suatu kebiasaan dalam penyampaian risalah kepada umat manusia, Allah SWT. menggunakan bahasa bangsa atau masyarakat yang menjadi sasaran dakwah, walaupun pesan-pesan Tuhan itu tidak dikhususkan buat bangsa itu saja. Al-Qur'an menegaskan bahwa "Kami tidak mengutus seorang rasul pun, melainkan dengan bahasa kaumnya, supaya dia dapat memberi penjelasan dengan terang kepada mereka." Maka Taurat diturunkan Allah kepada Nabi Musa as. menggunakan bahasa Ibrani sebagai bahasa kaumnya dan menurunkan Injil kepada Nabi 'Isa dengan bahasa Suryani sebagai bahasa kaumnya pula.

Al-Qur'an sebagai kitab terakhir diturunkan dalam bahasa Arab, karena memang sasaran awal dakwahnya bangsa Arab. Al-Qur'an mengambarkan hal itu: "Sesungguhnya Kami menurunkannya berupa al-Qur'an dengan berbahasa Arab, agar kamu memahaminya". ${ }^{2}$ Orang Arab sangat bangga dengan bahasa yang mereka gunakan. Mereka menyukai puisi dan prosa serta amtsâl.

Gaya bahasa al-Qur'an sangat indah, bahkan mengalahkan keindahan gaya bahasa puisi atau prosa gubahan sastrawan Arab terkemuka sekalipun. Disebabkan oleh keindahan bahasanya yang tidak tertandingi oleh manusia itulah, maka para ulama memandang bahwa aspek kebahasaan merupakan satu di antara sisi kemu'jizatan al-Qur'an. 'Abd al-Wahhab al-Khallâf mengemukakan empat aspek kemu'jizatan al-Qur'an, dua di antaranya berkaitan dengan bahasa, yaitu pertama keteraturan ungkapan serta makna dan kedua kefasihan lafaz serta keindahan ungkapan, yang besar pengaruhnya terhadap para pembaca dan para pendengarnya.

Abû Jahal bin Hisyâm, Abû Shufyan bin ㅂarb, dan al-Akhnas bin Syariq pernah saling berpesan agar tidak mendengarkan al-Qur'an. Mereka juga mengingatkan orang Arab agar tidak cenderung kepada Kitab Suci tersebut. Tetapi, karena begitu kuatnya pengaruh al-Qur'an, mereka secara diam-diam mendengarkan bacaan Nabi Muhammad. ${ }^{3}$ Dalam suatu riwayat dijelaskan, bahwa suatu ketika Nabi berdiri melaksanakan salat dan membaca al-Qur'an. Al-Walid bin al-Mughîrah berada di dekat Nabi mendengarkan bacaan Rasul tersebut, setelah memahami bacaan Nabi dia mengulang bacaan tersebut seraya berkata "seolaholah dia begitu mengasihinya". Kemudian al-Walid pergi kepada kaumnya Bani Makhzum, dan berkata "demi Allah saya baru saja ini mendengarkan dari Muhammad suatu ungkapan yang saya kira ungkapan itu bukanlah perkataan manusia dan jin. Sesungguhnya ungkapan itu benar-benar manis dan indah; di atasnya berbuah, di bawahnya melimpah, ia amat tinggi tidak ada yang lebih tinggi darinya. Ia benar-benar menghancurkan sesuatu yang di bawahnya". ${ }^{4}$

${ }^{1}$ Q.S. Ibrâhîm/14: 4.

${ }^{2}$ Q.S. Yûsuf / 12: 2.

${ }^{3}$ Muhammad Adnan Zarzur, 'Ulûm al-Qur'ân; Madkhal Ilâ Tafsîr al-Qur'ân wa Bayâni I'jâzih (Bairut: al-Maktab al-Islâmî, 1981), h. 222.

${ }^{4}$ Ibid., h. 224. 
Ungkapan ini jelas mengambarkan kekaguman al-Walid terhadap bahasa al-Qur'an. Tetapi kekagumannya terhadap Kitab Suci tersebut tidak membuat jiwanya mengakui kerasulan Nabi Muhammad dan mengimani al-Qur'an. Dia pada akhirnya mengatakan "al-Qur'an ini tidak lain hanyalah sihir yang dipelajari Muhammad dari orang-orang dahulu". 5

Bahasa mempunyai andil yang sangat besar terhadap pemahaman seseorang terhadap teks yang dibaca atau ungkapan yang didengar. Pemahaman pembaca atau pendengar terhadap teks atau ungkapan yang dibaca atau didengar belum tentu sesuai dengan apa yang dimaksud oleh pembicara atau penulis teks tersebut. Sebab itu, kebanyakan hasil penafsiran terhadap nas syar'i tetap menjadi nisbi; kebenarannya tidak sampai kepada tingkat mutlak (zhanni al-dalâlah), kecuali ungkapan-ungkapan yang mempunyai makna yang pasti (qath'i al-dalâlah), dimana tidak ada kemungkinan makna lain selain makna yang pasti itu.

Bahasa Arab mempunyai karakter yang memiliki banyak perbedaan dengan bahasa lain. Hal itu dapat dilihat dalam lafazyang digunakan yang mempunyai makna ganda (musytarak). Seperti lafaz-hurufjâr, yang mempunyai banyak makna. Memahamial-nushûsh al-qur'ûniyah huruf jâr menjadi suatu persoalan krusial. Penentuan makna ini perlu ijtihad, mujtahid perlu menganalisis sehingga dapat menentukan makna yang lebih pantas digunakan dalam ayat yang sedang ditafsirkan.

Para imam mujtahid sebagai penafsir ayat-ayat al-Qur'an terutama ayat-ayat hukum menghadapi persoalan-persoalan kebahasan seperti yang telah disebutkan di atas. Perbedaan dalam menafsirkan ayat-ayat ahk kam dilatarbelakangi juga oleh persoalan-persoalan kebahasaan. Tulisan ini mengkaji lebih dalam aspek-aspek kebahasaan yang mempengaruhi perbedaan para mujtahid.

\section{Problematika Bahasa Arab sebagai Alat Memahami al-Qur'an}

Bahasa adalah sistem lambang bunyi yang berartikulasi yang bersifat sewenang-wenang dan konvensional yang dipakai sebagai alat komunikasi untuk melahirkan perasaan dan pikiran. ${ }^{6}$ Kata "bersifat sewenang-wenang" dalam definisi ini menunjukkan, bahwa bahasa itu sembrono, tidak mempunyai aturan dalam menetapkan lambang suatu makna yang ditunjuk. Lambang hanya ditetapkan begitu saja tanpa aturan, bahkan tanpa ada kesepakatan sebelumnya antar para pengguna lambang tersebut. Para pengguna lambang mengikuti lambang suatu makna yang digunakan oleh orang sebelumnya. Karena tidak memiliki aturan dalam penentuan lafaz atau lambang suatu makna, maka kadang-kadang terjadi penggunaan suatu lambang bunyi yang menunjukkan banyak makna. Ambiguitas ini juga dimiliki oleh bahasa Arab. Bahasa Arab mempunyai beragam lafaz yang menunjukkan satu makna atau

${ }^{5}$ Q.S. Al-Muddatstsir/74: 24.

${ }^{6}$ Tim Penyunan Kamus Pusat Pembinaan dan Pengembangan Bahasa, Kamus Besar Bahasa Indonesia (Jakarta: Balai Pustaka, 1990), h. 66. 
beragam makna yang dimiliki oleh suatu lafaz, baik makna kata kerja (fi'il), kata benda (isim), ataupun kata sambung (hurûf).

Keambiguitasan bahasa Arab menyebabkan perbedaan para imam mujtahid dalam menafsirkan al-Qur'an terutama ayat-ayat yang berkaitan dengan hukum merupakan suatu keniscayaan. Sebab, tidak semua ayat al-Qur'an mempunyai makna yang jelas (al-muhkkamât), yang mengambarkan kepastian makna (qath'i al-dalâlah) yang dapat menggiring kepada keseragaman dalam memahami al-Qur'an. Al-Qur'an banyak menggunakan lafaz yang tidak mempunyai makna pasti atau samar-samar (al-mutasyâbihât). Status pemaknaannya tetap berada pada ketidakpastian (zhanni al-dalâlah), dimana hal ini berdampak kepada perbedaan atau ketidaksepakatan dalam pemaknaan terhadap suatu teks.

Persoalan lain yang terdapat dalam teks Arab (al-nushûsh al-'arabiyah) adalah penentuan maksud kata ganti (isim dhamîr), kemana dikembalikan. Perbedaan dalam menentukan maksud yang ditunjuk oleh isim dhamir jelas mempengaruhi makna. Demikian pula isim isyârah, untuk memahami teks seorang pembaca harus menentukan kata yang ditunjuk (musyârah ilaih) oleh isim tersebut. Perbedaan dalam menentukan musyârah ilaih berdampak pula kepada perbedaan pemahaman.

\section{Perspektif Kebahasaan dan Implikasinya terhadap Perbedaan Pendapat Para Mujtahid dalam Menafsirkan Ayat Hukum}

Paparan di atas menunjukkan banyak aspek kebahasaan yang tidak disepakati oleh para mujtahid dalam menafsirkan ayat-ayat hukum. Persoalan kebahasaan yang tidak mereka sepakati itu meliputi pemaknaan terhadap suatu kata, penentuan musyârah ilaih dari suatu isim isyârah, penentuan tempat kembali dhamîr, dan penentuan kait (muqayyad).

\section{Perbedaan Para Ulama dalam Pemaknaan Kata}

Kata dalam bahasa Arab meliputi isim (kata benda), fiìl (kata kerja), dan h hurûf (kata sambung). Ketiga jenis kata (kalimah) itu, walaupun dalam lafal yang sama, tidak selalu mempunyai makna yang sama pula. Ia kadang-kadang mempunyai makna ganda. Maka untuk menentukan satu di antara makna yang ada, seorang mujtahid perlu berijtihad, di mana hasil ijtihadnya bisa saja berbeda dengan mujtahid lainnya.

\section{Pemaknaan Huruf Jâr dan 'Athaf}

Terdapat banyak huruf jâr yang digunakan dalam ayat-ayat hukum, yang dapat mempengaruhi makna ayat terutama jika mempunyai lebih dari satu makna. Seperti Q.S. al-Mâ'idah/5: 6, yakni: 
Ada beberapa huruf jâr yang tidak disepakati maknanya oleh para imam mujtahid yang terdapat dalam ayat di atas, yaitu ilâ pada penggalan ayat ilâ al-marâfiq dan ila alka'bain. Selain itu, terdapat pula ba yang terdapat dalam ayat wamsahûu biru'ûsikum.

Dalam kaedah bahasa Arab, ilâ memiliki tiga makna yaitu al-intihâ', al-mushâhabah atau semakna dengan ma'a, dan semakna dengan 'inda. ${ }^{7}$ Jika ilâ dalam ayat ini bermakna intihâ' maka siku tidak termasuk bagian yang dibasuh, tetapi jika ia bermakna al-mushâhabah, maka siku termasuk bagian yang mesti dibasuh. Demikian pula ilâ pada penggalan ayat ila al-kabain (hingga dua mata kaki), jika ia diartikan kepada al-mushâhabah, maka mata kaki merupakan bagian dari kaki yang mesti dibasuh, tetapi jika ia diartikan kepada intihâ', maka mata kaki tidak termasuk bagian yang mesti dibasuh ketika membasuh kaki.

Jumhur ulama, yaitu Abû Hanifah, Mâlik, dan al-Syâfiî berpandangan bahwa ilâ dalam ayat tersebut berarti al-mushâhabah atau semakna dengan ma'a. Sebagian ahli zhahir dan sebagian pengikut mazhab Malik serta al-Thâbarî berpandangan pula bahwa ilâ dalam ayat tersebut bermakna al-ghâyah atau al-intihâ'. ${ }^{8}$

Selain ilâ terdapat pula dalam ayat di atas huruf ba yang juga mempunyai makna ganda, seperti yang terdapat dalam penggalan ayat . Dalam kaedah Bahasa Arab, ba huruf jâr mempunyai banyak makna. Mushtafa Ghulayainî menjelaskan bahwa ba mempunyai tiga belas makna. Di antara makna yang dapat digunakan dalam ayat di atas adalah al-ta'kîd yaitu ziyâdah (tambahan) dan tab'îdh (sebagian). ${ }^{9}$ Para ulama tidak sepakat dalam memaknai huruf ba yang terdapat dalam penggalan ayat ini. Di antara mereka mengartikan kepada al-ta'kîd atau sebagai ziyâdah (tambahan), sehingga makna huruf itu tidak berpengaruh kepada makna kalimat, karena ia hanya sebagai tambahan saja. Maka berdasarkan arti tersebut, kalimat sama maknanya dengan

(tanpa $b a$ ). Imam mujtahid yang memaknai ba dengan makna ini adalah Imam Mâlik. Sedangkan Abû Hanifah dan al-Syâfi'î mengartikannya kepada tab’îdh sehingga, menurut mereka, penggalan ayat sama artinya dengan (sapulah sebagian kepalamu).

${ }^{7}$ Musthafa Ghulayni, Jâmi' al-Durûs al-Arabaiyah, jilid III (Bairut: Maktabah al-'Ashriyah, 1989.), h. 173-174.

${ }^{8}$ Abû al-Wâlid Muhammad bin Ahmad bin Muhammad bin Ahmad Ibn Rusyd, Bidâyah al-Mujtahid fì Nihâyah al-Muqtashid, Jilid I (Semarang: Usaha Keluarga. t.t.), h. 8.

${ }^{9}$ Al-Ghulayni, Jâmi‘ al-Durûs, Jilid III, h. 171. 
Selain huruf jar, dalam ayat itu terdapat pula huruf'athaf yang juga dapat menimbulkan pemahaman ganda sesuai dengan gandanya makna huruf tersebut. Huruf'athaf yang dimaksud adalah waw pada penggalan ayat wa aydiyakum dan wa arjulakum. Para ahli Nahu berbeda pendapat dalam memaknai waw huruf 'athaf ini. Para tokoh Nahu Bashrah berpendapat, bahwa waw hanya mempunyai makna muthlaq jama', ia tidak mempunyai faedah tartîb dan ta'qî̉. Pendapat ini dipegangi pula oleh Musthafa Ghulayainî dalam karyanya Jâmi ${ }^{\natural}$ al-Durûs al-Lughah al-'Arabiyah. Dia mengatakan:

Sebaliknya para tokoh Nahu Kufah berpendapat, bahwa waw 'athaf selain jam'u ia

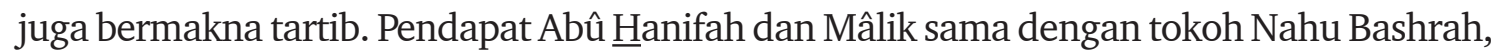
sehingga menurut mereka waw 'athaf dalam ayat di atas hanya bermakna jam'u saja tidak ada tertib dan ta'qîb. Sedang al-Syâfiî̀ dan Ahmad bin Hanbal sependapat dengan aliran Nahu Kufah, yaitu bahwa waw 'athaf tidak hanya bermakna jam‘u saja, tetapi juga tartîb dan ta'qî́b.

\section{Pemaknaan terhadap Kata Benda (isim) dan Kata Kerja (fi'il)}

Pemaknaan suatu kata dalam menafsirkan ayat-ayat hukum juga persoalan yang selalu tidak disepakati oleh para ulama, dimana perbedaan itu mempunyai konsekuensi munculnya perbedaan pendapat dalam . Dalam Q.S. al-Mâ’idah/5: 6 di atas terdapat beberapa kata yang tidak mereka sepakati maknanya, yaitu antara lain lâmasa dan shaîdan thayyiban.

Pertama. Kata lâmasa terdapat dalam penggalan ayat . Kata ini semakna dengan massa. Ia juga mempunyai makna ganda, yaitu menyentuh dengan tangan sebagai makna dasar dan mempergauli atau mencampuri sebagai makna majazi. Seperti yang tergambar dalam ayat, bahwa tidak ada kepastian salah satu di antara kedua makna tersebut. Maka para ulama bebas berijtihad dalam menentukan makna yang dimaksud dalam ayat di atas. Abû Hanifah mengartikan kata lâmasa itu kepada jimak atau menyampuri, sesuai dengan makna majazinya. Sedangkan Imam Mâlik dan al-Syâfiî mengartikannya pula kepada makna dasar lâmasa itu sendiri, yaitu bersentuhan kulit. Perbedaan ini melahirkan perbedaan pendapat mereka mengenai bersentuhan laki-laki dan wanita, yang membuat batalnya wuduk. Menurut $\underline{H} a n a f i$, maksud sentuhan dalam ayat itu ialah jimak. Sedangkan Imam Mâlik dan al-Syâfi'î berpendapat pula, bahwa sentuhan yang membuat batalnya wuduk itu adalah bersentuhan kulit.

Kedua. Sha'îda, secara etimologi kata shaî̀da berasal dari kata sha'ada. Makna dasarnya

${ }^{10}$ Ibid, h. 245. 
adalah "terangkat." Al-sha î̀d bermakna bumi yang terangkat atau agak tinggi. Para ulama berbeda pendapat dalam menentukan makna terminologi kata shaîd dalam ayat ini. Menurut al-Syâfiî̀, kata itu bermakna "tanah yang mengandung debu." Menurut Abû Ishâa, sha îd berarti wajhu al-ardh (permukaan bumi). ${ }^{11}$ Perbedaan-perbedaan ini jelas menimbulkan ikhtilâf dalam menetapkan benda yang boleh dijadikan untuk bertayamum.

Perbincangan di atas mengambarkan perbedaan para ulama dalam memaknai kata yang terdapat dalam ayat-ayat mengenai ibadah. Perbedaan seperti ini juga terdapat dalam menafsirkan ayat-ayat hukum tentang muamalah. Hal itu misalnya pemaknaan terhadap kata qurû', nakaha, tathahharna, dan i'tazilû.

(1) Kata qurû'. Kata tersebut terdapat dalam Q.S. al-Baqarah/2: 228:

Kata qurû' merupakan jamak dari qar', ia mempunyai dua makna, yaitu al-haydhu (haid) dan al-thahru (suci). Kedua makna ini digunakan dalam bahasa Arab. Pemaknaan kata qar'u kepada suci dan haid merupakan pengembangan dari makna dasarnya, yaitu al-waqt. ${ }^{12}$ 'Abd al-Wahab 'Abd al-Salam secara umum mengartikan qar'u itu kepada "waktu dimana pada saat itu sudah biasa terjadi suatu kejadian tertentu." ${ }^{13}$ Masa haid dan suci disebut dengan al-qar'u karena ia merupakan masa khusus dan biasa terjadi pada setiap wanita pada waktu-waktu tertentu. Kemudian istilah qar'u ini secara umum diartikan kepada haid dan suci tersebut. Para mujtahid tidak sepakat dalam memaknai kata qar'u dalam ayat di atas. Abû Hanifah mengartikannya kepada haid, dan Imam al-Syâfi'î mengartikannya pula kepada suci. Pendapat al-Syâfi'î ini didukung oleh kata tsalâtsata qurû' dalam ayat itu, yang menggunakan 'adad (kata bilangan) dalam bentukmu'annats. Dalam kaedah bahasa Arab, apabila ‘adad-nya mu'annats, maka ma'dud-nya mestilah mudzakkar yaitu al-athahru (suci). Bukan al-haydhah, karena ia mu'annats, jika yang dimaksud dengan qurû' dalam ayat itu haid, maka lafalnya tsalâtsa qurû' bukan tsalâtsata qurû.' ${ }^{14}$

(2) Kata nikâh. Kata nikâh yang tidak disepakati maknanya, antara lain dapat dilihat dalam Q.S. al-Nisâ'/4: 22,

${ }^{11}$ Abî al-Fadhl Jamal al-Dîn Muhammad bin Mukrim Ibn Manzhur, Lisân al-Arab, Jilid III (Bairut: Dâr al-Fikr, 1990), h. 254.

${ }^{12}$ Ibid., Jilid I, h. 130.

${ }^{13}$ 'Abd al-Wahab 'Abd al-Salam Thawilah, Atsr al-Lughah fí Ikhtilâfi al-Mujtahidîn (Kairo: Dâr al-Salam, 2000), h. 91.

${ }^{14}$ Muhammad 'Alî al-Shâbunî, Rawâ'i' al-Bayân Tafsîr Ayât al-Ahkkâm min al-Qur'ân, Jilid I (Dimasyq: Dâr al-Qalam, 1990), h. 306. 
Secara umum, ayat ini bermakna, bahwa seseorang dilarang menikahi wanita yang telah pernah dinikahi oleh ayahnya, kecuali pernikahan yang sudah terlanjur sebelum turun larangan ini. Perbuatan menikahi wanita yang telah dinikahi oleh ayah itu adalah perbuatan yang keji.

Persoalan yang muncul dalam penafsiran ayat di atas adalah makna kata nakaha Kata nakaha merupakan lafaz musytarak. Ia mempunyai makna ganda, yaitu makna lughawi dan makna istilah. Nikah secara bahasa bermakna jimak atau hubungan seksual, dan secara istilah nikâh bermakna akad ijab kabul yang dilakukan oleh wali nikah dan calon suami.

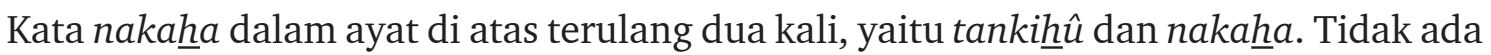
perbedaan pendapat ulama dalam memaknai kata tankihي̂u, yaitu akad nikah. Mereka berbeda dalam memaknai kata nakaha , yang terdapat pada kalimat mâ nakaha. Jika kata nikah dalam ayat ini diartikan menurut makna etimologinya, maka ayat itu bermakna bahwa seorang anak tidak boleh menikahi wanita yang telah pernah dipergauli oleh ayahnya, walaupun pergaulan itu tidak halal. Tetapi jika kata tersebut diartikan kepada akad, maka yang dilarang hanya menikahi wanita yang telah pernah dinikahi oleh ayah. Maka berdasarkan makna ini, seseorang boleh menikahi wanita yang pernah dicampuri oleh ayahnya tanpa akad nikah. Abû Hanifah, al-Tsawri, al-Awzâ'î, dan Qatadah mengartikan kata nikâh $\underline{\text { dalam }}$ ayat ini kepada maknanya secara bahasa, yaitu jimâ'. Sedangkan al-Syâfi'î, al-Laytsî, alZuhrî, dan mazhab Mâlik mengartikannya kepada akad. ${ }^{15}$

(3) Kata tathahharna, yang terdapat dalam Q.S. al-Baqarah/2: 222,

Kata tathahhara dalam ayat ini merupkan fi'il mâdhi jama' mu'annats, yang berasal dari kata thahura. Kata tersebut telah mendapatkan tambahan ta dan satu huruf yang sejenis dengan 'ain fiìlnya. Secara harfiah, thahura bermakna suci, dan tathahharna bermakna mereka telah suci. Tetapi, tidak ada kepastian mengenai maksud suci (tathahhara) dalam ayat tersebut; apakah dalam makna putusnya darah haid (inqithâ' dam al-haydh) kemudian membasuh al-mahîtdh (tempat keluar haid), atau dalam arti inqithâ' dam al-haydh dan mandi?. Hal ini tidak disepakati oleh para ulama.

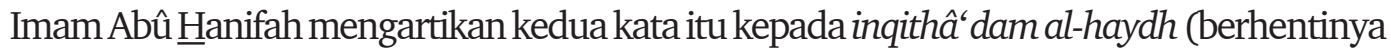
darah haid). Maka katayathhurna dalam ayat menurutya semakna dengan tathahharna dalam ayat . Dengan demikian, ayat itu berarti "janganlah kamu dekati mereka sehingga darah haidnya berhenti keluar, dan apabila darah mereka itu telah berhenti maka datangilah mereka". Sedangkan Jumhur

\footnotetext{
${ }^{15}$ Ibid., h. 428.
} 
ulama berpandangan pula, bahwa kata yathurna mempunyai makna yang berbeda dari kata tathahharna. Katayathhurna bermakna inqithaâ' dam al-haydh, sedangkan tathahharna berarti ightasalna (mandi). Sebab itu, menurut mereka ayat itu bermakna "janganlah kamu dekati mereka sehingga darah haidnya berhenti keluar, dan apabila mereka telah mandi (setelah darah mereka itu berhenti keluar) maka datangilah mereka".

\section{Penentuan Musyârah Ilaih dari Suatu Isim Isyârah}

Perbedaan para ulama dalam menafsirkan ayat hukum juga dilatarbelakangi oleh perbedaan dalam menentukan musyârah ilaih (kata yang ditunjuki oleh) suatu isim isyârah . Perbedaan menentukan musyârah ilaih tersebut mempunyai konsekuensi terhadap perbedaan makna, seperti pertama. Penafsiran ayat tentang pelaksanaan haji tamattu', yaitu:

Dalam ayat di atas, terdapat ungkapan

"hal itu bagi orang-orang, dimana keluarganya bukan penduduk Masjidil Haram/Kota Makkah". Persoalan yang tidak disepakati oleh para mufasir adalah ungkapan atau lafal mana yang ditunjuki oleh kata $d z a ̂ l i k a ~(i t u)$ dalam ayat tersebut. Sebelumnya diperbincangkan tentang haji tamattu', yaitu melaksanakan umrah sebelum haji di bulan haji. Seorang Muslim boleh mengerjakan haji tamattu ' dengan syarat membayar dam salah satu di antara dua hal, yaitu mengurbankan seekor binatang ternak atau berpuasa sepuluh hari; tiga dilaksanakan semasa melaksanakan ihram haji dan tujuh hari lainnya apabila telah pulang ke tempat tinggal. Kemudian penggalan ayat berikutnya menyatakan "

"hal itu bagi orang-orang, dimana keluarganya bukan pendudukMasjidil Haram/Kota Makkah". Apakah yang dimaksud dengan "hal itu" dalam ayat ini? Ada dua kemungkinan lafal yang ditunjuki oleh $d z a ̂ l i k a$ tersebut, yaitu kebolehan melaksanakan haji tamattu ' dan kewajiban membayar dam jika melaksanakan haji tamattu '. Abû Hanifah berpendangan, bahwa musyârah ilaih kata $d z a ̂ l i k a$ dalam ayat ini adalah haji tamattu '. Sedangkan Imam Mâlik, al-Syâfi'î, dan Ahmad berpendapat pula bahwa lafal yang tunjuki oleh $d z a ̂ a l i k a$ adalah kewajiban membayar dam. ${ }^{16}$

Berdasarkan penentuan musyârah ilaih itu, Imam Hanafi berpandangan bahwa haji tamattu' hanya boleh dilakukan oleh orang yang bukan penduduk kota Makkah. Sedangkan jumhur ulama, berdasarkan penentuan mereka terhadap musyârah ilaih dalam ayat tersebut, berpendapat pula bahwa dam haji tamattu' hanya diwajibkan kepada orang-orang yang

${ }^{16} I b i d .$, h. 236. 
bukan penduduk kota Makkah. Penduduk kota Makkah yang mengerjakan haji tamattu“ tidak dikenakan dam.

Kedua. Penafsiran ayat tentang hukum mengawini pezina, yang terdapat dalam Q.S al-Nûr/: 3, yakni:

Para ulama tidak sepakat dalam menafsirkan ayat ini, khususnya hukum menikah dengan pezina. Perbedaan itu dilatarbelakangi oleh ketidaksepakatan mereka dalam memaknai penggalan ayat wahurrima dzâlika 'ala al-mu'minîn, khususnya menentukan lafal yang ditunjuk oleh $d z a ̂ l i k a$. Ada mufasir yang berpendapat, bahwa kalimat yang diisyaratkan oleh $d z a ̂ l i k a$ adalah nikâh al-zâni (menikahi pezina) dan nikâh al-musyrik (menikahi orang musyrik), yang terkandung dalam penggalan ayat sebelumnya. Jumhur ulama berpandangan, bahwa kata dzâlika dalam ayat tersebut diisyaratkan kepada al-zina bukan kepada alnikâh. Karena itu, menurut mereka, boleh bagi orang baik-baik ('afif atau 'afifah) menikah dengan pezina. ${ }^{17}$ Pendapat ini, di kalangan sahabat, dinukilkan dari Abû Bakar, 'Umar, dan Ibn 'Abbâs yang kemudian dianut oleh jumhur ulama seperti Hanafi dan al-Syâfi'î. Selain jumhur, terdapat pula ulama yang berpandangan, bahwa kata dzâlika diisyaratkan kepada al-nikâh. Karena itu, mereka berpandangan tidak boleh menikah dengan pezina. Dari kalangan sahabat, hal ini diriwayatkan dari 'Ali, al-Barra', dan 'A'isyah. ${ }^{18}$

\section{Penentuan Tempat Kembali Dhamîr}

Perbedaan pendapat para mujtahid dalam menafsirkan ayat-ayat hukum juga dilatarbelakangi oleh perbedaan mereka dalam menentukan tempat kembali isim dhamîr yang terdapat dalam ayat hukum tersebut. Hal itu seperti yang terlihat pada komentar dan penjelasan mereka terhadap ayat-ayat mengenai tayamum di atas, yaitu penggalan Q.S. al-Mâ'idah/5: 6,

Dan jika kamu junub maka mandilah, dan jika kamu sakit atau dalam perjalanan atau kembali dari tempat buang air (kakus) atau menyentuh perempuan, lalu kamu tidak memperoleh air, maka bertayammumlah dengan tanahyang baik (bersih); sapulah mukamu dan tanganmu dengan tanah yang suci.

Dalam ayat di atas terdapat isim dhamîr yaitu (kamu), yang merupakan kata

\footnotetext{
${ }^{17}$ Ibn Rusyd Bidâyah al-Mujtahid wa Nihâyah al-Muqtashid, Jilid II, h. 30.
}

${ }^{18}$ Al-Shâbunî, Rawâ'i‘u al-Bayân, Jilid II, h. 49. 
ganti orang kedua jamak (jama'mukhâtab). Sebelumnya terdapat pula beberapa kata ganti orang kedua jamak, dimana perbincangan diarahkan kepada orang-orang (kamu) yang telah junub, orang-orang sakit, orang dalam perjalanan, orang-orang yang sudah buang air besar, dan orang yang telah bersentuhan dengan wanita. Secara garis besar perbincangan ayat ini dapat dikategorikan kepada dua macam, yaitu orang-orang (kamu) yang telah berhadas besar (junub) dan orang (kamu) yang telah berhadas kecil, yang meliputi buang air besar dan bersentuhan dengan wanita.

Dalam penggalan ayat

juga terdapat kata ganti orang kedua jamak, yang menjelaskan kebolehan bertayammum bagi orang yang tidak mendapatkan air. Persoalan yang menjadi perdebatan di sini adalah maksud antum yang terdapat dalam penggalan ayat ini; apakah semua orang yang diperbincangkan dalam ayat sebelumnya atau sebagiannya, yaitu orang-orang yang berhadas kecil saja?. Para mujtahid tidak sepakat dalam menentukan siapa yang dimaksud dengan antum (kamu) dalam penggalan ayat tersebut. 'Umar dan Ibn Mas'ud berpandangan, bahwa dhamîr antum yang terdapat dalam penggalan ayat ini kembali kepada orang-orang yang berhadas kecil saja, dalam ayat itu disebutkan orang yang sudah buang air dan bersentuhan dengan wanita. Sedangkan 'Ali bin Abî Thâlib dan sahabat lainnya berpendapat pula, bahwa dhamîr itu tidak hanya kembali kepada orang yang berhadas kecil saja, tetapi juga kembali kepada orang yang telah berhadas besar (junub).

\section{Cakupan dan Kualitas Makna Suatu Lafaz}

Pertama. Takhshish al-'Am. Dalam al-Qur'an, banyak terdapat ayat 'âmm, dimana ia dipahami dan diamalkan berdasarkan keumumannya itu tanpa takhshish. Sebaliknya, terdapat pula ayat-ayat 'âmm yang tidak dipahami dan diamalkan berdasarkan keumumannya itu, tetapi ia di-takhshish-kan oleh ayat lain atau Sunnah Nabi. Para ulama kadang-kadang tidak sepakat dalam menentukan keberlakuan umunya suatu ayat. Suatu ayat ' $a m m$, yang dipahami dan ditafsirkan berdasarkan keumumannya itu oleh seorang mujtahid belum tentu juga dipahami dan ditafsirkan sedemikian rupa oleh mujtahid lainnya. Hal itu dapat dilihat dalam penafsiran ayat-ayat berikut:

(1) Penafsiran terhadap kata al-‘ahillah dalam Q.S. al-Baqarah/2: 189:

Mereka bertanya kepadamu tentang bulan sabit. Katakanlah: "Bulan sabit itu adalah tandatanda waktu bagi manusia dan (bagi ibadat) haji.

Secara umum ayat ini menjelaskan, bahwa bulan sabit itu adalah waktu pelaksanaan ibadah haji. Bulan sabit itu ada di setiap bulan. Maka berdasarkan ini menurut mereka, ihram haji itu boleh dilaksanakan kapan saja baik dalam bulan haji ataupun tidak. 
Kata al-ahillah dalam ayat di atas bersifat ' $\mathrm{a} m m$, ia ada di setiap bulan. Para mujtahid berbeda dalam memaknai kata tersebut; Apakah ia dipahami dan diamalkan sesuai keumumannya, atau ia telah di-takhshish-kan sehingga tidak lagi diartikan sesuai keumumannya itu. Imam

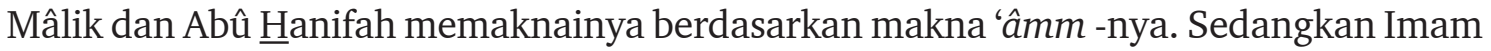
al-Syâfi'î melihat, keumuman kata al-ahillah dalam ayat 189 surat al-Baqarah itu telah di-takhshîsh-kan oleh ayat . Maka dengan demikian menurutnya, bulan sabit yang dimaksud dalam ayat 189 itu adalah bulan sabit yang ada di bulan haji, tidak termasuk bulan sabit pada bulan lainnya.

(2) Penafsiran ayat mengenai pemberian mut'ah oleh suami kepada isteri yang telah diceraikannya, yaitu:

Kata al-muthallaqât dalam ayat ini adalah lafaz 'âmm. ㅂasan al-Bashri memaknai kata tersebut sesuai dengan lafaz 'âmm -nya. Menurutnya, ayat itu berarti, seorang lakilaki wajib memberikan mut'ah kepada perempuan yang telah diceraikannya. Mâlik berpandangan, suami hanya sunat memberikan mut'ah kepada wanita yang telah diceraikannya itu. Dalil yang menunjukkan sunat itu adalah penggalan ayat yang terdapat di bagian akhir ayat 245 di atas, yaitu haqqan 'ala al-muttaqîn. Sedangkan Jumhur berpandangan, bahwa al-muthalaqât dalam ayat itu memang ' $\hat{a} m m$ tetapi ia dipahami secara khas. Maka mereka berpendapat mut'ah hanya wajib atas laki-laki untuk wanita yang dicerai dimana wanita itu belum menentukan jumlah maharnya. Sebaliknya, wanita yang dicerai setelah ditentukan maharnya, dan telah dibayar, hanya sunat diberi mut'ah. Pendapat ini juga diriwayatkan dari Ibn 'Umar, Ibn 'Abbâs dan Ali bin Abî Thâlib. ${ }^{19}$ Dalil yang menunjukkan khasnya makna muthallaqât dalam ayat tersebut adalah firman Allah yang terdapat dalam ayat sebelumnya, yaitu Q.S.al-Baqarah/ 2: 236. Ayat itu menyebutkan, bahwa wanita yang dicerai sebelum dipergauli dan belum pula ditentukan maharnya wajib diberi mut'ah.

(3) Penafsiran ayat tentang haramnya seorang laki-laki menikahi wanita yang pernah menyusukannya atau saudara sesuan. Ayat itu adalah:

Dalam ayat di atas terdapat kata ummahâtukum al-lâtî ardha'nakum dan akhawâtukum min al-radhâ'ah. Ayat ini adalah umum, yaitu siapapun wanita yang menyusukan dan berapapun frekuensi menyusu termasuk dalam larangan itu. Hal ini dipegangi oleh mazhab

${ }^{19}$ Ibid., h. 354-355. 
Mâliki, Abû Hanifah, al-Awza'î, dan al-Tsawrî. Dari kalangan sahabat, terdapat pula 'Alî, Ibn Mas'ûd, Ibn 'Umar, dan Ibn 'Abbâs yang juga berpandangan bahwa ayat itu dipahami dan diamalkan berdasarkan makna umumnya itu. ${ }^{20}$

Tetapi selain mereka ini, terdapat pula para mujtahid yang tidak memaknai ayat itu dalam keumumannya. Menurut mereka, ayat itu telah di-takhshish-kan oleh ayat yang telah di-mansukh-kan tulisannya sebagaimana dinyatakan dalam hadis riwayat 'A'isyah:

"Pernah diturunkan sebagian dari (ayat) al-Qur'an (yang menerangkan) diharamkan (menikahi kalau) menyusu sudah sampai sepuluh kaliyang dimaklumi. Kemudian dinasakhkan dengan lima kali (menyusu) yang dimaklumi. Kemudian Rasul wafat, dan ia masih dibaca sebagai bagian dari al-Qur'an" (HR. Muslim). ${ }^{21}$

Berdasarkan hadis ini mereka berpandangan, terdapat batas minimal frekuensi menyusu sebagai persyaratan keharaman menikahi wanita yang menyusukan dan saudara sesuan. Namun mereka berbeda pula dalam menentukan batas minimal tersebut. Perbedaan itu adalah bahwa menurut Abû 'Ubaid dan Abû Tsur, batas minimal itu adalah tiga kali menyusu. Al-Syâfi'î berpandangan, bahwa batas minimal itu adalah lima kali menyusu. Bahkan ada sebagian ulama yang berpendapat, batas minimalnya ialah sepuluh kali menyusu. ${ }^{22}$

Selain itu terdapat pula hadis, yang diriwayatkan dari 'Abd Allâh bin aldia terima dari Ummi al-Fadhl. Bahwa Nabi bersabda:

Tidaklah diharamkan sekali atau dua kali menyusu, atau sekali hisap dua kali hisap. ${ }^{23}$

(4) Penafsiran terhadap ayat mengenai kebolehan tahallul pada masa melaksanakan ibadah haji jika dikepung oleh musuh (al-ihhshâr), yang terdapat dalam Q.S. al-Baqarah/2: 196:

Ayat ini memberikan keringan untuk ber-tahallul kepada orang yang sedang ihram, dimana mereka terhalang oleh musuh. Persoalan yang tidak disepakati adalah makna kata al-ihsshâr dalam ayat di atas. Secara harfiah, al-ihhshâr bermakna al-habs (tertahan atau terhalang). Tetapi apakah yang dimaksud dalam ayat itu semua bentuk halangan, atau khusus terhalang

\footnotetext{
${ }^{20} \mathrm{Ibn}$ Rusyd, Bidâyah al-Mujtahid, Jilid II. h. 27

${ }^{21}$ Al-Kahlani, Subul al-Salâm, Jilid III (Bandung: Dahlan, t.t.), h. 216.

${ }^{22}$ Ibid.

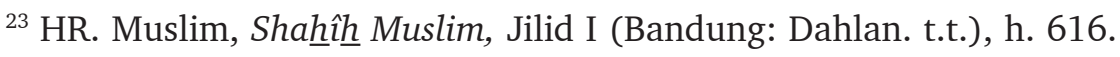


oleh musuh. Jumhur ulama berpandangan, yang dimaksud dengan halangan (al-ihhshâr) dalam ayat tersebut hanyalah tertahan atau terhalang oleh musuh, tidak termasuk halangan lainnya. Artinya, jumhur memaknai kata al-ihhshâr tersebut dalam makna sempit, ia tidak mencakupi makna lain. Sedangkan Abû Hanifah memaknai kata al-ihhshâr itu dalam arti luas, tidak hanya dalam arti terkepung atau terhalang oleh musuh saja. Menurutnya, halanganhalangan lain seperti sakit, takut, hilangnya kendaraan, dan lain-lain termasuk hal-hal yang membolehkan ber-tahallul.

(5) Penafsiran terhadap ayat mengenai larangan menikahi perempuan musyrik (al-musyrikât). Hal itu terdapat dalam Q.S. al-Baqarah/2: 221, yaitu:

Para ulama tidak sepakat dalam menafsirkan kata al-musyrikât dalam ayat ini. Jumhur ulama berpandangan, bahwa kata al-musyrikât dalam ayat ini tidak mengandung makna kafir kitabi (kitabiyât), yaitu wanita Yahudi dan Nasrani. Mereka berdalil dengan perbincangan al-Qur'an itu sendiri, yang membuat perbedaan antara ahl al-kitâb dengan al-musyrik. Ketika al-Qur'an berbincang mengenai musyrik, maka tidak termasuk di dalam ahl alkitâb. Sebab itu, kata al-musyrikât dalam ayat di atas tidak mencakupi kitabiyât. Sebaliknya, Ibn 'Umar berpendapat pula bahwa al-musyrikât dalam ayat itu juga mencakupi kitabiyât. Lebih jauh, dia mengatakan "Saya tidak tahu, apakah ada syirik yang lebih besar dari perkataan seorang wanita tuhannya Isa". ${ }^{24}$ Perbedaan ini berimplikasi kepada perbedaan mereka dalam menetapkan hukum mengenai kebolehan seorang laki-laki Muslim menikahi kitabiyât.

(6) Penafsiran terhadap kata i‘tizâl, yang terdapat dalam Q.S. al-Baqarah/2: 222: Dalam ayat tersebut ditegaskan "fa'tazilu al-niasâ'a fi al-mahîidh" (Jauhilah isterimu yang sedang dalam masa haid).

Persoalan yang menjadi perdebatan disini adalah apakah yang dimaksud dengan "menjauhi isteri dalam masa haid" (ittizâl al-nisấ fi al-mahîîh). Apakah sekujur badannya atau bagian tertentu saja? Ada mufasir yang memaknai ayat itu secara umum, dan ada pula yang memaknainya secara khusus. Mufasir yang memaknainya secara umum adalah suatu pendapat yang diriwayatkan dari Ibn 'Abbâs dan 'Ubaidah al-Salmanî. Sedangkan jumhur ulama memaknainya secara khusus. Menurut mereka, yang dimaksud dengan i'tizâl al-nisâ'fi al-mahî̀dh tidaklah sekujur badannya tetapi bagian tertentu saja. Namun demikian, jumhur berbeda pula dalam menentukan bagian tubuh wanita yang mesti dijauhi dalam masa haidnya itu. Perbedaan itu adalah 1) Menurut mazhab ㅂanafi dan Mâliki, bagian yang wajib dijauhi itu ialah mulai dari pusat sampai lutut. 2) Al-Syâfiî berpandangan

${ }^{24}$ Al-Shâbunî, Rawâ'i‘u al-Bayân, Jilid I, h. 268. 
pula, bahwa yang mesti dijauhi hanyalah kemaluan, tempat yang sedang kotor (mawdhi $a l-a d z a) .^{25}$

\section{Kualitas Suatu Perintah dan Larangan}

Perbincangan mengenai hukum pastilah berkaitan dengan perintah atau larangan. Kualitas suatu perintah dan larangan tidak selalu sama antara satu kalimat dengan kalimat lainnya. Kualitas kalimat perintah yang paling tinggi adalah wajib, tetapi kadang-kadang ia juga bermakna suatu anjuran atau kebolehan atau tidak bernilai apa-apa (mubâh $\underline{\text { ). Kalimat }}$ larangan yang paling tinggi adalah haram, tetapi kadang-kadang ia juga bermakna suatu anjuran agar ditinggalkan, tidak sampai berdosa mengerjakannya.

Al-Qur'an sebagai sumber hukum selalu menggunakan kalimat perintah dan larangan. Tidak semua kalimat perintah dalam al-Qur'an bermakna wajib, dan tidak semua larangan dalam al-Qur'an bermakna haram. Para imam mujtahid kadang-kadang tidak sepakat dalam memaknai kalimat perintah atau larangan tersebut. Suatu kalimat perintah yang dimaknai sebagai wajib oleh sebagian mujtahid belum tentu juga wajib dalam pandangan mujtahid lainnya, demikian pula kalimat larangan. Perbedaan-perbedaan dalam pemaknaan ini tentu saja melahirkan pula perbedaan dalam menetapkan hukum. Hal itu dapat dilihat dalam dua contoh berikut:

Pertama. Perintah menikah yang terdapat dalam al-Qur'an. Hal ini seperti yang terdapat dalam ayat:

Dalam ayat ini terdapat kata perintah, yaitu fankihhu. Walaupun kata fankihي̂u, diungkapan dalam bentuk fi'il al-amr tetapi ia tidak mesti diartikan kepada wajib. Menurut Jumhur, kata perintah dalam ayat tersebut bermakna sunat tidak wajib. Sedangkan menurut $A h l$ al-Zhahir, kalimat perintah dalam ayat di atas bermakna wajib. Artinya, mereka berbeda dalam memandang kualitas kata perintah dalam ayat tersebut. Ahlu Zahir berpendapat, bahwa kualitas perintah tersebut berada pada peringkat wajib, sedangkan Jumhur berpendapat pula kualitasnya tidak sampai pada tingkat wajib; ia hanya merupakan perintah sunat.

Kedua. Perintah membaca basmallâh ketika menyembelih binatang. Hal ini seperti yang terdapat dalam firman Allah Q.S. al-Anâm/:121, yakni:

Dan janganlah kamu memakan binatang-binatangyang tidak disebut nama Allah ketika menyembelihnya. Sesungguhnya perbuatan yang semacam itu adalah suatu kefasikan.

${ }^{25}$ Ibid., h. 278. 
Dalam ayat ini terdapat fi íl nahi, yaitu larangan memakan sembelihan yang tidak menyebut nama Allah. Bahkan, hal itu disebut dengan perbuatan fasiq (innahû lafisq). Selain larangan atau ficil nahi, terdapat pula perintah menyebut nama Allah ketika melepas binatang pemburu, yaitu:

Dan sebutlah nama Allah (ketika melepas) binatang buas itu. Dan bertakwalah kepada Allah, sesungguhnya Allah amat cepat hisab-Nya.

Para ulama tidak sepakat memaknai kedua penggalan ayat di atas, terutama memaknai larangan dan kata perintah yang terdapat di dalamnya. Jumhur ulama yang terdiri dari Ahl Zahir, Abû Hanifah, Mâlik, dan Tsawrî berpandangan, bahwa larangan dalam ayat di atas berkualitas haram dan kata perintahnya bermakna wajib. Sedangkan menurut Imam al-Syâfi'î, larangan itu tidak bermakna haram tetapi hanya bermakna makruh. Perintah tidak bermakna wajib, tetapi bermakna sunat. Berdasarkan perbedaan perspektif kebahasaan ini, maka mereka pun berbeda dalam menetapkan hukum. Perbedaan itu adalah bahwa menurut mazhab Zhahiri (kaum tekstual), membaca basmallâh ketika menyembelih wajib secara mutlak. Menurut Abû Hanifah, Mâliki, dan al-Tsawrî, membaca basmalah ketika menyembelih adalah wajib dan merupakan syarat sahnya sembelihan jika teringat, tetapi jika terlupa maka wajibnya menjadi gugur. Al-Syâfi'î berpandangan, membaca basmallah ketika menyembelih bukanlah syarat sahnya sembelihan. Menurutnya, membaca basmalah ketika menyembelih hanyalah sunat mu'akkad.

Selain memaknai larangan kepada makruh dan suruhan kepada sunat, Imam alSyâfi'î juga berdalil sabda Nabi yang diriwayatkan dari Imam Mâlik yaitu:

Ada orangyang bertanya kepada Rasulullah; Ya Rasul, sesungguhnya ada orang dari masyarakat badwi datang kepada kami membawa daging dan kami tidak tahu apakah mereka menyebut nama Allah (ketika menyembelihnya) atau tidak? Maka Rasul menjawab; "Sebutlah nama Allah, kemudian makanlah".

Imam al-Syâfi'î cenderung melakukan al-jam'u (kompromi) terhadap dua nas yang ta'ârudh (bertentangan) ini, dengan cara menakwilkan larangan dalam ayat kepada makruh. Sehingga dia berpendapat, membaca basmalah itu sunat bukan wajib. Selain itu, ayat diartikan kepada larangan memakan sembelihan menyebut selain Allah, bukan larangan memakan sembelihan yang tidak membaca basmallâh. 


\section{Penentuan Qaid (Muqayyad)}

Perbincangan al-Qur'an mengenai norma, ketentuan, atau hukum yang harus dipatuhi manusia selalu dikaitkan dengan kondisi, sifat, atau persyaratan tertentu, dimana jika kondisi, sifat, atau persyaratan itu tidak ada maka hukum atau ketentuan akan berubah. Tetapi penyebutan al-Qur'an mengenainya tidak serta merta menjadi atau persyaratan keberlakuan suatu hukum. Seperti larangan Allah mewarisi kaum wanita dengan cara paksa, sebagaimana yang tergambar dalam ayat

(Hai orang-orang yang beriman tidak halal bagi kamu mewarisi wanita itu dengan cara dipaksa). ${ }^{26}$ Penyebutan kata paksa (karhan) dalam ayat ini jelas bukan menjadi kait keharaman mewarisi wanita. Artinya, baik terpaksa ataupun suka, wanita tetap tidak boleh diwarisi. Sebab, kata karhan dalam ayat di atas itu hanya mengambarkan kondisi wanita yang diwarisi itu pada umumnya terpaksa.

Tidak ada batasan yang jelas mengenai kait yang mempengaruhi hukum dan yang tidak mempengaruhinya. Sebab itu, persoalan ini selalu memicu munculnya perbedaan dalam penafsiran. Hal itu dapat dilihat dalam penafsiran berbagai ayat, baik yang menyangkut dengan ibadah ataupun muamalah. Untuk lebih jelas akan disajikan penafsiran ayat berikut:

Pertama. Penafsiran terhadap ayat mengenai kebolehan mengasar salat, yang terdapat dalam Q.S. al-Nisâ'/4: 101:

Dan apabila kamu bepergian di muka bumi, maka tidaklah mengapa kamu men-qashar sembahyang(mu), jika kamu takut diserang orang-orang kafir. Sesungguhnya orang-orang kafir itu adalah musuh yang nyata bagimu.

Ayat ini menegaskan mengenai kebolehan seorang Muslim yang dalam musafir mengashar salat, dengan menjadikan salat yang empat rakaat menjadi dua rakaat. Tetapi kebolehan itu diiringi dengan ungkapan

(jika kamu takut diserang orang-orang kafir), sehingga soalah-olah ayat itu bermakna "bahwa apabila kamu dalam perjalanan maka kamu boleh mengashar salatmu dengan syarat jika kamu takut diganggu orang-orang kafir". Yang menjadi persolan disini adalah "apakah huruf syarat dalam ayat itu merupakan kait terhadap kebolehan mengashar salat atau tidak? Jika tidak, apa urgensi dan makna in khiftum ayyaftinakum al-ladzîna kafarû dalam ayat ini?. Jika ia menjadi syarat, maka ayat itu mengandung makna bahwa orang yang tidak khawatir mendapat gangguan dari orang-orang kafir dalam perjalanannya tidak boleh mengashar salat. Para mujtahid tidak sepakat dalam memaknai in syarthiyah dalam ayat tersebut. Jumhur ulama

${ }^{26}$ Q.S. al-Nisâ' /4: 19. 
berpandangan ungkapan in khiftum ayyaftinakum al-ladzîna kafarû yang terdapat dalam ayat itu tidaklah merupakan kait, tetapi menggambarkan kebiasaan (aghlabiah) yang terjadi. Sedangkan, 'A'isyah berpandangan pula, bahwa penggalan ayat itu merupakan kait terhadap penggalan ayat falaysa 'alaykum junâhun an taqshurû min al-shalâh ${ }^{27}$

Kedua. Penafsiran terhadap ayat mengenai kebolehan menikah dengan anak tiri dan mertua, yang terdapat dalam Q.S. al-Nisâ'/4: 34:

Dan (juga diharamkan bagimu) menikahi ibu isterimu dan anak tirimu yang berada dalam jagaanmu dari isterimu dimana kamu telah mempergaulinya. Jika kamu belum menggaulinya, maka tidak ada dosa bagimu (menikahinya).

Terdapat dua kait dalam ayat ini, yaitu:

1.

(yang berada dalam jagaanmu) yang terdapat setelah kata

(anak tirimu), dan yang terdapat setelah kata min nisâ'ikum. Persoalan yang diperdebatkan di sini adalah "apakah kata menjadi kait dan membatasi kemutlakan atau tidak?". Hal inilah yang tidak disepakati oleh para ulama. Jumhur ulama berpandangan, bahwa kata tidaklah menjadi kait bagi sehingga kata yang terakhir ini tetap dipahami secara mutlak, dan tidak ada pembatasan makna kecuali kait yang terdapat setelah min nisâ'ikum, yaitu

(dari isterimu yang kamu pergauli). Atau dengan kata lain, kemutlakan kata rabâ'ibukum hanya dibatasi maknanya oleh kata sedangkan kata tidaklah membatasi makna atau tidaklah menjadi kait bagi kemutlakan kata . Sebaliknya, 'Ali bin Abî Thâlib berpendapat bahwa kedua kata (al-latî fi hujûrikum dan al-latî dakhaltum bihin) tersebut menjadi kait atau membatasi kemutlakan kata rabâ'ibukum. ${ }^{28}$

2 .

(dimana kamu telah bergaul dengan isterimu itu). Para ulama sepakat, bahwa kata ini merupakan kait bagi kata . Artinya, anak tiri yang haram dinikahi hanyalah anak tiri dimana ibunya telah dipergauli. Apabila ibunya belum dipergauli, kemudian dia diceraikan, maka anak itu boleh dinikahi. Tetapi para mujtahid tidak sepakat mengenai sebagai kait bagi kata yang terdapat sebelum kata . Menurut jumhur ulama, kata allatî dakhaltum bihinna tidaklah kait atau tidaklah membatasi kemutlakan kata ummahâtu nisâikum. Justru itu, menurut mereka mesti dipahami secara mutlak, kait sifat yang terdapat dalam ayat itu hanya

${ }^{27}$ Ibn Rusyd, Bidâyah al-Mujtahid, Jilid I, h. 120.

${ }^{28}$ Muhammad Jamâl al-Dîn al-Qâsimî, Mahâasin al-Ta’wîl, Jilid V (t.tp.: Dâr Ihyầ' al-Kutub al-Arabiyah, 1957), h. 1179. 
berlaku pada rabâ'ibukum saja. Sedangan Ali bin Abi Thalib berpandangan, bahwa kait itu tidak hanya berlaku terhadap rabâ’ib tetapi juga berlaku terhadap kata ummahât. Maka menurutnya, kata tidak dipahami secara mutlak tetapi dikaitkan dengan al-latî dakhaltum bihinn. ${ }^{29}$

\section{Makna Hakiki dan Majazi}

Selain dari persoalan kebahasaan di atas, perbedaan pendapat para mujtahid dalam menafsirkan suatu ayat juga dilatarbelakangi oleh pandangan mereka tentang makna hakiki dan majazinya suatu ayat. Perbincangan al-Qur'an mengenai suatu persoalan kadangkadang bersifat hakiki dan kadang-kadang bersifat majazi. Ungkapan yang bersifat hakiki itu secara jelas dapat dipahami kehakikiannya, demikian pula ungkapan majazi sehingga tidak ada menimbulkan perbedaan pendapat. Tetapi, ada pula ungkapan hakiki dan majazi yang tidak dapat dipahami secara pasti; apakah ia pasti hakiki atau pasti majazi. Inilah yang melahirkan perbedaan dalam penafsiran. Hal itu dapat dilihat dalam penafsiran Q.S. alBaqarah/2: 184:

Para ulama berbeda dalam memahami kalimat

(siapa saja di antaramu yang sakit atau dalam perjalanan, maka dia mesti berpuasa sejumlah hari dia sakit atau dalam perjalanan tersebut di hari-hari yang lain). Sebagian ulama berpandangan bahwa ada kata yang di-mahzuf-kan dalam ayat tersebut, yaitu fa afthara sehingga menurut mereka ayat itu bermakna

(siapa saja di antaramu yang sakit atau dalam perjalanan lalu dia berbuka atau tidak berpuasa, maka dia mesti berpuasa sejumlah hari berbukanya itu di hari-hari yang lain). Jumhur ulama menafsirkan ayat di atas seperti penafsiran ini. Sedangkan $A h l$ Zhahir berpandangan, bahwa tidak ada kata yang di-mahzuf-kan. Menurut mereka ayat tersebut mesti dipahami sebagaimana adanya, yaitu dalam makna hakiki. ${ }^{30}$

Artinya, menurut jumhur ulama ayat di atas termasuk majaz nuqshan yaitu tidak menyebutkan kata fa afthara karena telah dimaklumi. Ulama lainnya berpendapat, bahwa ayat di atas mengandung makna hakiki, tidak ada kata yang dihilangkan. Karenanya, ia mesti dimaknai dengan makna hakiki itu. Maka orang yang sedang dalam perjalanan mestilah berpuasa di luar Ramadhan sejumlah hari perjalanannya itu.

${ }^{29} I b i d .$, h. 1177.

${ }^{30}$ Ibn Rusyd, Bidâyah al-Mujtahid, Jilid I, h. 215. 


\section{Penutup}

Munculnya perbedaan pendapat para ulama dalam merupakan suatu keniscayaan. Maka pemahaman dan pengamalan umat Islam terhadap ajaran agamanya, khususnya persoalan-persoalan, tidak mungkin disatukan. Banyak faktor yang memicu munculnya perbedaan-perbedaan pandangan atau pemahaman terhadap hukum Islam itu, yang tentu saja melahirkan pula perbedaan dalam pengamalan. Faktor tersebut meliputi perbedaan mereka dalam berdalil, perbedaan mereka dalam menilai kualitas atau status suatu nas, terutama hadis, perbedaan metodologi yang mereka gunakan dalam menghadapi dalildali yang saling bertentangan (ta'ârudh al-adillah), dan perbedaan mereka dalam persoalan kebahasaan.

Ada beberapa hal yang berkaitan dengan kebahasaan yang melatarbelakangi perbedaan pendapat dalam menafsirkan ayat-ayat hukum, yaitu pertama pemaknaan terhadap suatu kata yang terdapat dalam ayat-ayat hukum. Hal itu meliputi pemaknaan terhadap huruf jar, huruf 'ataf, penentuan makna suatu kata kerja dan kata benda yang berlafal musytarak. Kedua penentuan persoalan yang ditunjuki oleh suatu isim isyârah. Ketiga penentuan tempat pengembalian isim dhamîr yang terdapat dalam ayat-ayat hukum. Keempat penentuan cakupan dan kualitas makna suatu lafal, yang meliputi keberlakuan umumnya sebuah lafal dan pen-takhshish-annya, kualitas suatu perintah dan larangan, serta muthlaq dan muqayyadnya sebuah lafal. Kelima pemaknaan hakiki dan majazinya suatu lafal.

Itulah lima persoalan kebahasaan yang selalu diperdebatkan oleh para mujtahid, yang melatarbelakangi terjadinya perbedaan pendapat mereka dalam menafsirkan ayatayat hukum. Selanjutnya perbedaan itu melahirkan pula perbedaan pendapat dalam menetapkan hukum Islam. Perbedaan pendapat para ulama yang disebabkan oleh persoalan kebahasaan ini mencakupi semua bagian hukum Islam tersebut, baik persoalan yang menyangkut dengan persoalan ibadah ataupun yang menyangkut dengan persoalan muamalah. Persoalan ibadah mencakupi hal-hal yang berkaitan dengan salat, puasa, zakat, dan haji. Persoalan muamalah mencakupi pula hal-hal yang berkaitan dengan makanan, dan perkawinan.

Persoalan kebahasaan kadang-kadang tidak berdiri sendiri dalam mempengaruhi munculnya perbedaan pendapat dalam menafsirkan suatu ayat hukum atau menetapkan suatu hukum. Sering sekali alasan kebahasaan yang dipegangi oleh seorang mujtahid ditopang pula dalil lain, seperti hadis dan qiyas.

\section{Pustaka Acuan}

'Abd al-Wahab 'Abd al-Salam. Atsru al-Lughah fì Ikhtilâfi al-Mujtahidîn. Kairo: Dâr alSalâm, 2000.

Abû Zahrah, Muhammad. Ushûl al- Fiqh. t.t.p: Dâr al-Fikri al-Aarabi, t.t.

Al-Ahdal, Muhammad bin Ahmad bin 'Abd al-Bari.Al-Kawâkib al-Durriyah Syarh $\underline{\text { Mutammimah }}$ al-Ajrumiyah. Surabaya: Toko Imam. t.t. 
Al-Damanhurî, Aḥmad. Îdhâh al-Mubham min Ma'âni al-Sulam. Cerebon: Syirkah Mathba'ah Indonesia, t.t.

Ghulayainî, Musthafa. Jâmi' al-Durûs al-Aarabiyah. Bairut: al-Maktabah al-Ásriyah, 1989. Ibn Katsir, 'Imâd al-Dîn Abîal-Fidâ' Ismầil. Tafsîr al-Qurân al-Azhîm. Bandung: Syirkah Nurasia, t.t. Ibn Manzur, Abî al-Fadl Jamal al-Dîn Muhammad bin Mukrim. Lisân al-'Arab. Bairut: Dâr al-Fikr, 1990.

Ibn Rusyd, Abû al-Walid Muhammad bin Aḥmad bin Muhammad bin Ahmad. Bidâyah al-Mujtahid fĩ Nihâyah al-Muqtashid. Semarang: Usaha Keluarga, t.t.

Al-Jazîrî, Abdurrahmmân. Kitâb al-Fiqh Alâ Madzâhib al-Arba'ah. Bairut: Dâr Thyâ' al-Turats, 1969.

Al-Jawi, Syaikh Muhammad Nawâwî. Al-Tafsîr al-Munîr li Ma‘âlim al-Tanzîl Jilid I. Bandung; Syirkah al-Ma'arif., t.t.

Khallâf, 'Abd al-Wahhab. 'Ilm Ushûl al-Fiqh. Kuwait: t.p, t.t.

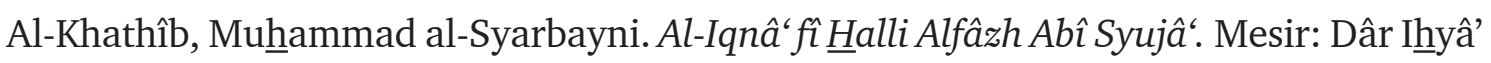
al-Kutub, t.t.

Kadar M. Yusuf. Tafsir Ayat Ahkam: Tafsir Tematik Ayat-ayat Mengenai Hukum. Jakarta: Amzah, 2011. Al-Kahlani, Muhammad Ibn Isma'il. Subul al-Salâm. Bandung: Maktabah Dahlan, t.t.

Muslim. Shahîh $\underline{h}$ Muslim. Bandung: Dahlan. t.t.

Al-Maraghî, Aḥmad Mushtafâ. Tafsîr al-Marâghî. Bairut: Dâr al-Fikr, 1974.

Sâbiq, al-Sayyid. Fiqh al-Sunnah. Bairut: Dâr al-Fikr, 1983.

Al-Shâbûni, Muhammad 'Ali. Rawẩi al-Bayân Tafsîr Ayât al-Ahkkâm min al-Qur'ân. Dimasyq: Dâr al-Qalâm, 1990.

Al-Shabûnî, Muhammad 'Alî. Shafwah al-Tafâsâr. Bairut: Dâr al-Jayl. t.t.

Al-Thabarî, Abî Ja'far ibn Jarîr. Jâmi' al-Bayân Ta’wîl Âyi al-Qur'ân. Bairut: Dâr al-Fikr, 1988.

Al-Tirmîdzi, Abî 'Îsâ Muhammad bin 'Îsâ bin Surat. Sunan al-Tirmîdzi wa huwa al-Jâmi' al-Shahîh. Bandung: Maktabah Dahlan, t.t.

Tawilah, 'Abd al-Wahab 'Abd al-Salâm. Atsr al-Lughah fỉ Ikhtilâfi al-Mujtahidîn. Kairo: Dâr al-Salâm, 2000.

Tim Penyunan Kamus Pusat Pembinaan dan Pengembangan Bahasa. Kamus Besar Bahasa Indonesia. Jakarta: Balai Pustaka, 1990.

Al-Qurthubi, Abû 'Abdillah Muhammad ibn Aḥmad al-Anshâri. Al-Jâmi‘ li Ah\#kâm alQur'ân, t.t.p: Dâr al-Kutub al-Mishriyah, 1954.

Al-Qâsimi, Muhnammad Jamâl al-Dîn. Mahhâsin al-Ta'wîl. t.tp: 'Îsâ al-Bâbi al-

Al-Qaradhâwî,Yusuf. Fiqh al-Zakah. Bairut: Muassasah al-Risâlah, 1991.

Zarzur, Muhammad Adnan. 'Ulûm al-Qur'ân: Madkhal Ilâ Tafsîr al-Qur'ân wa Bayâni I'jâzih. Bairut: al-Maktab al-Islâmî, 1981.

Al-Zuhaylî, Wahbah, Al-Fiqh al-Islâmi wa Adillatuh. Damaskus: Dâr al-Fikr, 2004. 